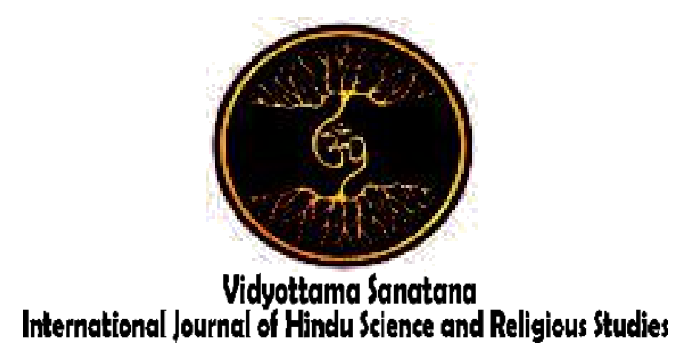

Vol. V No. 1 June 2021

\title{
MANAGEMENT OF MENTAL DISORDER PATIENTS (ADHIATMIKA DHUKA) IN BALI PROVINCE HOSPITALITY
}

\author{
By \\ I Nengah Sumantra \\ Universitas Hindu Negeri I Gusti Bagus Sugriwa Denpasar \\ E-mail: nengahsumantra45@gmail.co.id
}

Received: February 12, 2021

Accepted: Juni 30, 2021

Published: June 30, 2021

\begin{abstract}
This research is focused on the discussion of (1) integration between traditional and conventional medicine in the RSJ (Mental Hospital) of Bali, (2) the form of a combination of traditional medicine with conventional medicine for mental disorder patients at Mental Hospital of Bali, (3) the impact of integrating traditional medicine and conventional in mental patients at Mental Hospital of Bali. The theory used in analyzing the three problem formulations in this study, namely: (1) psychoanalytic theory, (2) ethnomedicine theory, and (3) perception theory. This research uses the method of documentation, literature study, observation and interviews. The results of this study indicate the following points. First, the factors that cause psychiatric rehabilitation patients at RSJ Bali integrate traditional and conventional medicine consisting of internal factors, e.g., beliefs, needs for holistic nursing care, religion, social, and culture, and also external factors, e.g., state legitimacy towards traditional medicine and western biomedical weakness. Second, the form of traditional medicine for mental illness patients at RSJ Bali Province consists of traditional forms, e.g., diagnosis (nengerin), peruwatan (bhuta Yajna) and spells, speech, dharma wacana (spiritual ceremony), prayer, and text-based handling (manuscripts) of medicine and a combination of traditional and modern techniques, and also conventional forms of treatment for psychoanalysis, cognitive behavioral approaches (cognitive behavior), humanistic approaches, and other types of therapy. The form of combining traditional and modern techniques consists of diagnosis, improvement of mental development, the use of drugs, and treatment by spiritual means. Third, traditional and conventional treatments for mental patients at RSJ Bali have an individual impact, social impact, psychological impact on patients, the impact of power, and the impact of community culture.
\end{abstract}

Keywords: treatment, mental illness, adhyatmika dukha 


\section{INTRODUCTION}

Modern life today has appeared in two antagonistic faces. On the one hand, modernism has succeeded in bringing about spectacular progress, especially in the fields of science and technology. On the other hand, the condition has presented the hazy face of humanity in the form of modern humanity as spiritual misery. Modernity has dragged humans into spiritual aridity. This is a logical consequence of the modern paradigm which is too materialistic and mechanistic with elements of normative values that have been neglected.

Mental disorders in the Balinese Hindu tribe are rooted in the Ayurvedic scriptures and various usada books. Based on this description, this study focuses on (1) the integration between traditional and conventional medicine in the Bali Provincial Hospital, (2) the form of a combination of traditional medicine with conventional medicine for mental disorders patients at the Bali Provincial Hospital, (3) the impact of integrating traditional medicine and conventional in mental patients at RSJ Bali Province. The theory used in analyzing the three problem formulations in this study, namely: (1) psychoanalytic theory, (2) ethnomedicine theory, and (3) perception theory. This study uses the method of documentation, literature study, observation and interviews.

The results of this study indicate the following points. First, the factors that cause psychiatric rehabilitation patients at RSJ Bali Province integrate traditional and conventional medicine consisting of internal factors and external factors. Internal factors include beliefs, needs for holistic nursing care, religion, social, and culture. The external factors consist of the State's legitimacy of traditional medicine and the weakness of western biomedicine. Second, the form of a combination of traditional medicine for mental patients at RSJ Bali Province consists of traditional forms of treatment, conventional forms of treatment, and a combination of traditional and modern techniques.
Forms of traditional medicine include diagnosis (nengerin), pegruwatan (bayuh oton) and mantras, speech, dharma discourse (spiritual siraman), prayer, and text-based handling (manuscripts). Conventional forms of treatment consist of psychoanalysis, cognitive behavior approaches, humanistic approaches, and other types of therapy. The form of combining traditional and modern techniques consists of diagnosis, improvement of mental development, the use of medicines, and treatment by spiritual means. Third, the impact of traditional and conventional medicine on mental patients at RSJ Bali Province includes the individual impact, social impact, psychological impact on patients, the impact of family power, and the impact of community culture.

Based on the problematic gap between dasolene and dasein as described in the background above, the problems in this study can be formulated as follows.

(1) Why do mental disorders rehabilitation patients at RSJ Bali Province integrate traditional and conventional medicine?

(2) How is the combination of traditional and conventional medicine for mental rehabilitation patients at RSJ Bali Province?

(3) How is the impact of integrating traditional and conventional medicine on mental disorders rehabilitation patients at RSJ Bali Province?

\section{RESEARCH RESULT}

\section{Factors That Cause Mental Disorder Rehabilitation Patients in Bali Provincial RSJ Integrate Traditional and Conventional Medicine}

The type of treatment undertaken by mental disorders patients at RSJ Bali Province does not only involve a technical-normative process. When we look closely, the classification of treatment for mental health patients at RSJ Bali Province is influenced by their subconscious conditions. The factors that cause mental disorders patients at RSJ Bali Province to integrate traditional and conventional medicine are influenced by two 
factors, namely internal and external factors which are described as follows.

\section{Internal factors}

(1) Faith Factor. In Hinduism, belief is termed sradha. Masduki and Warsah (2020: 296) state that belief can encourage religious followers to make sacrifices, live in submission, or be patient with suffering. In line with that, Putri (2018: 139) states that a person's recovery is not only influenced by medical or physical problems of the sick person, but is also closely related to various social and cultural elements that also greatly affect a person's recovery.

(2) The Needs for Holistic Nursing Care, Putri (2018: 113-114) states that nursing care is one of the concepts in the world of nursing which has a number of meanings which when put together have very deep and very practical meanings. Nursing care is a process or sequence of activities in a nursing practice. This concept directly targets clients or patients in various healthcare systems. Putri (2018: 23) revealed that nursing prioritizes improving health and disease prevention rather than treatment after the disease occurs.

(3) Religious factors, appreciation of religious values is recognized by several scientists, that religion has a broad and profound effect on human health, both physical, spiritual, and social in nature (Sudarma, 2008: 51). The search for healing through religion will eventually give birth to a medical system that seems to be an integral part of a particular religion.

(4) Social Factors, Putri (2008: 140) states that various social problems usually occur when an individual has an imbalance with their environment. This imbalance usually occurs in the social, economic and educational spheres. The root is, an individual does not pay attention to his health problems. Slowly, the individual will commit acts of violence. Their social background, including their daily habits, is a very determining indicator.

(5) Cultural factors, Putri (2008: 44-45) states that people have their own culture towards the existence of health workers such as nurses in carrying out their duties facing the community. The nurse will have a tendency to impose or apply beliefs, practices, and values, on the culture of another person or higher group. This higher position than other groups is because medical personnel or nurses in them feel they have value and knowledge in science and profession as experts in their fields. This condition is called cultural imposition. The condition of health workers which is called cultural imposition then underlies Leininger's thought to interpret the concept of the transcultural nursing paradigm as a perspective, belief, values, concepts in the implementation of nursing care to the four centers of nursing, namely human, healthy, environmental and nursing in accordance with cultural background.

\section{External Factors}

(1) Legitimacy of State Regulations on Traditional Medicine, Putri (2008: 53) states that traditional medicine is the embryo of the birth of nursing professionals. Until now, traditional medicine still exists and continues to develop in people's lives. Traditional medicine and medicine are an integral part of the healthy range of illnesses that are used by the community in overcoming various health problems in both villages and big cities. Various types of traditional medicine and medicine have been known since the days of human ancestors and developed in line with the development of social culture.

(2) Weaknesses of West Biomedicine, diachronic traces that traditional ingredients have been found since 2000 BC. Even the inventions at that time are still in use today. Both in India, China, Egypt, Greece, Japan, and Korea have 
ancient ingredients that are also spread in Indonesia. Not only that, even magnets have been used as tools for healing in ancient times. This proves that technology has existed since ancient times even though it is still in its simplest form. Traditional medicine and medicine were created by humans because of a problem at hand.

The construction of a health service center also cannot be balanced. The WHO report (2006) states that Indonesia is one of the 57 countries facing a human resource crisis in health, both in insufficient numbers and in distribution. In 2015, the ratio of health workers in Indonesia was still 1 to 4,000 people. Therefore, humans must create technology to meet the problem of shortages of medical personnel by developing health technology. When there is a shortage of medical personnel, community nursing care is needed. Nurses will be helped by working together to restore clients. Many inventions have been made and technological advances, both in the field of hospital organization, medicine, as well as development research and health science itself.

\section{Form of Traditional Medicine Integration for Rehabilitation Patients of Mental Disorders at Mental Hospital of Bali}

The system for treating mental illness patients at RSJ Bali Province can be divided into two parts, namely traditional and conventional, which are described as follows:

\section{Forms of traditional medicine}

(1) Diagnosis of the type of madness. The large variety of mental disorders causes the first step of traditional medicine carried out at the Provincial RSJ, of course, the same as that carried out in modern mental therapy, namely to diagnose or listen. Sugiharta (2020: 1-2) states that the word tatěngerr comes from the root word tĕngĕr which means characteristic, sound, or contains a distinctive element. For example, there is the sentence kulkul banjare nganti dini matěngěran (the banjar's kentongan is heard up to here). This means that the listener can confirm if the sound he hears comes from the banjar kentongan, not from other kentongan or other sound objects. The ability to come to that conclusion must be based on repeated listening experiences. Or compare it with the next sentence Tĕngĕran munyine I Dugdug uli joh suba maciri (the echo of I Dugdug's voice from afar was already ketara). The listener could quickly recognize I Dugdug by the characteristics of his voice even though he didn't see his face directly.

(2) Pengruwatan (bayuh oton) and mantras. Basically, cleansing in the ceremony has two objectives, namely, first the cleansing of the place (nature) and the disturbances and bad influences caused by bhuta-kalas and beings who are considered lower and human as mentioned above. The second is cleansing of bhuta-kala and these beings, with the aim of eliminating the evil qualities that exist in him, so that his good qualities and powers can be of use to the welfare of mankind and nature. Pengruwatan (bayuh oton) in Bali is also accompanied by certain mantras. Titib (2003: 28) states that mantras function as suti, stava, stotra or puja which means to glorify the greatness of God Almighty, His manifestation deities, ancestors and holy teachers. In this sense it includes asking for safety, mercy, tranquility and happiness. In its function of asking for self-protection, the mantrarn functions as Kavaca (magical clothes that protect the human body and mind from negative or evil forces) and Pañjara (fortify the family from various obstacles or crimes.

(3) Speech and dharma wacana (spiritual siraman). The traditional way which also plays a role in providing holistic healing for mental patients is through speech or discourse dharma. Tutur means words, words, words (Poerwadarminta, 1985: 1113). Agustina (2004: 50) states that speech acts are an individual psychological symptom, and their occurrence is determined by the speaker's language skills in dealing with certain situations. Dharmawacana comes from the words dharma and discourse. Several definitions of dharma have been found. The word 
Dharma, comes from Sanskrit, which means the subject of teaching; doctrine; law; Constitution; order (Country, world, nature), regulations; religion, belief; worship; way of life; customs; virtue; To use; services; good / holy deeds; (justice); (truth); (to) sunyata (an); right; obligation; task (Mardiwarsito 1985: 171). The word discourse is a series of words or a series of speech actions that express something that is presented regularly, systematically, in a coherent unity, formed by segmental or nonsegmental language.

(4) Prayer, concentration of mind is a part of Raja yoga which also has an important role in the success of Raja Yoga. Those who pray are essentially concentrated so that a mind can be completely controlled. Only the trained mind can control the body, can contemplate and meditate endlessly as long as life rolls, never once losing its object of search and contemplation, never once let it become ensnared by any temptation. All kinds of physical activity should be completely restricted, all attachments should be eliminated completely by disciplined practice. Through the practice of concentrating the mind during prayer a person gradually becomes aware of God through the concentration of the mind. Old habits such as thinking about things that are not important should be completely stopped, because this activity will make the mind scatter and strengthen worldly ideas.

(5) In handling mental disorders that originate in the text (manuscript), Simanjuntak (2008: 72-74) states that almost all healing processes in the culture of the tribes in the archipelago are influenced by Hindu elements. Hindu religious concepts that came from India preserved pre-existing local religious elements. Jero Mangku Apel said that the most commonly used references for lontar to treat insanity are Lontar Cukil Daki and Lontar Usadha Buduh.

\section{Conventional forms of treatment}

(1) Psychoanalysis, echoed by Sigmund Freud in the late 19th century. Psychoanalysis believes in the existence and power of the subconscious dimensions of the human mind. It is in this unconscious condition that there are hidden conflicts and defense mechanisms.
(2) Cognitive behavior approach (cognitive behavior), Manuntung (2018: 68) calls cognitive therapy a psychotherapy approach that aims to solve problems regarding dysfunctional emotions, behavior and cognition through goal-oriented and systematic procedures. This viewpoint yields testable theories and powerful and effective therapeutic methods. In general, this approach focuses on eliminating or reducing problematic behavior, not on the causes of the behavior. The cognitivebehavioral approach seeks to assess and treat symptoms of the disorder and focuses on demonstrable behavior.

(3) Humanistic approach, Hartini and Ariana (2016: 72) state that the main goal of the humanistic approach is personal selfdevelopment and self-actualization. Something that the humanistic approach commonly addresses is the belief in one's self-determination. Humanistic orientation is more focused on the present and the future rather than the past. Beliefs and their expressions take precedence over the limited rational thinking of traditional science. The humanistic approach tends to look hopefully at a person's potential rather than the mental disorders and behavior change symptoms that patients experience.

(4) Other types of therapy, then there are other approaches that do not fall into the three main categories in the treatment of mental disorders patients at RSJ Bali Province, namely: Hypnosis, which is a way to relax and put aside conscious thoughts (conscious mind), and Therapy. focused on solutions based on a positive and optimistic view of human nature.

Forms of joining traditional and modern techniques

(1) Diagnosis, can be done either traditional or modern. Clyne (in Sugiharta, 2020: 2) states that the diagnosis comes from Greek, namely from the verb diagignoskein which means to differentiate. In fact, diagnosis plays an important role in the treatment process, both modern and traditional. Misdiagnosis, apart from causing the futility of treatment or obstruction of the healing process, also endangers the patient's life due to wrong treatment. Traditionally according to Delf and Manning (in Sugiharta, 2020: 2, the diagnosis is carried out in four ways, namely seeing (inspection), feeling 
(palpation), tapping (percussion), and hearing (auscultation).

(2) Improving mental development, handling patients Mental disorders can also be done by improving the patient's mental development.In a medical view, the treatment of the patient's mental development is carried out by focusing on exploring the relationship between a person's thoughts, feelings, and behavior.Mental improvement therapy traditionally carried out at RSJ Bali Province involves two main things, namely karma yoga and jnana yoga Karma yoga includes training in daily activities such as gardening, washing, cleaning furniture, etc. While jnana yoga includes activities such as religious lectures as well as individual guidance for patients, which in turn can broaden the patient's spiritual horizons.

(3) Treatment by utilizing drugs, in terms of herbs al as well as pharmacological drugs for mental disorders including consumption drugs and foreign drugs. Common medicines that are used medically at the Bali Provincial Hospital are those that are antipsychotic, which can help reduce or eliminate hearing of unwanted sounds and very scary thoughts. Antidepressants, which are also used in medicine, can help reduce negative feelings such as sadness or a depressed mood and anxiety and suicidal thoughts. Other drugs are sedatives and sleeping pills that can reduce anxiety and insomnia and help patients feel more relaxed. Other drugs are sedatives and sleeping pills that can reduce anxiety and insomnia and help patients feel more relaxed. While traditionally the medicines used either come from parts of the body of animals, plants, or inanimate objects around humans.

(4) Handling in a spiritual way. The definition of spirituality that developed in the postomodern era is increasingly varied. Spirituality is not only said in ancient ways but new methods that are more modern and practical are emerging. Generally spiritual descriptions often include transcendence and an openness to explore relationships with higher powers or values.

Impact Of Integrating Traditional And Confensional Medicine On Rehabilitation
Patients Of Mental Disorders At Rsj Provinsi Bali

\section{Individual Impact}

The earliest impact of integrating traditional and conventional medicine in RSJ Bali Province is related to perception. This perception was born after the observation process was carried out by each individual. Perception appears as an internal process carried out to select, evaluate and organize stimuli and the external environment. In other words, perception is the human way of converting the physical energies of an individual's environment into meaningful experiences. Perception determines when humans choose messages and ignore other messages. The higher the degree of similarity of individual perceptions, the easier and more often the individual communicates and as a consequence the more likely they are to form cultural groups or identity groups. Perception is described as an impression which is the nuance of human feeling to a certain object, that object can be either things or people. humans are impressed by it because there is something interesting and that object.

The sensation itself means an awareness of the stimulus that enters the five senses. Thus, it makes a good impression depending on and yourself because everyone's reaction is different in facing the same stimuli, and every human being reacts to stimuli. Therefore, humans must be good at taking lessons and always think positively is the best way to prepare a stimulus by reducing suspicion, especially excessive suspicion.

Sensation (sensai), through the sense organs. The meaning of the messages sent to the brain must be learned by these senses. All senses have a share in the ongoing human communication. Sight conveys non-verbal messages to the brain for interpretation. Hearing also conveys verbal messages to the brain for interpretation. Information is obtained from sensation, memory, and other cognitive processes. The attention process helps to efficiently use limited mental 
resources, which in turn will help speed up reactions to certain stimuli.

The theory of learning behaviorism is often called psychological S-R, which means that human behavior is controlled by reward and reinforcement and the environment. From Thorndike and Watson to the present day, behaviorists have held that organisms are born without social or psychological characteristics. Watson once described the way of thinking of a Behaviorist and the motto is that if he is given a baby and the power and freedom to raise it, then he is able to make the baby crawl, walk, climb and use both hands to build buildings of stone or wood, being a thief, shooter or, narcotic addict or the possibility to shape a person in any direction is almost limitless.

A child may learn to repay the humiliation he received at school by asking the taunter to fight because the father always gives credit when the individual is defending his rights. While in the imitation process, people often study social attitudes and behaviors by imitating the attitudes and behaviors that become models, this is what is meant by imitation. Imitation can occur without external reinforcement, only through casual observations of the model. The three processes of behavior occur in the process of developing individual responses at the Bali Provincial RSJ.

In the operant conditioning theory, it is stated that there are two kinds of responses, namely respondent response and operant response. Respondent response (reflexive response or respondense behavior) is a response generated by certain stimuli called electing stimuli which are relatively fixed and limited in nature and the relationship between stimulus and response is certain, so it is less likely to be modified, for example foods that cause saliva. Operant response (instrumental response or instrmental behavior) is a response that arises and develops followed by certain stimuli, which are called reinforcing stimuli or reinforcers.

These observations emphasize attention to organized forms (organized firms) and patterns of human perception.
Understanding and perceptions of relationships in entities are essential to learning. Gestalt psychology is also known as field field theory or commonly known as cognitive field theory. This group of thought agrees on one point which is a basic principle that human experience has a rich field which contains the phenomenon of the whole more than its parts.

Then how someone can solve problems in learning consists of several things such as realization, proposing hypotheses, collecting data or information, assessing and trying to prove hypotheses, and drawing conclusions. In the realization of the problem, humans must understand what the problem is and must also be able to formulate the problem.

A further emphasis on this field psychology is the purposeful nature of human behavior. Individuals create responses based on insight (insight) into the situation they are facing. His behavior will be judged smart or stupid depending on whether or not he has an adequate understanding of the situation.

Individuals adapt to their environment through social interaction with the state of the environment where they are. The form of adjustment can be in the form of autoplastic and allow plastic. Autoplastic is passive in nature, that is, the individual adapts to the state of his environment, for example a nurse who is on duty in the room shows good manners, does not wear luxury items, is neatly dressed, hair is neatly arranged, walks gracefully does not rush freely, and others. While Alloplastic is active, that is, individuals change the environment to suit their circumstances or desires.

\section{Social Impact}

Social impact is actually built by individual perceptions involving interpersonal communication. Interpersonal communication is the process of sending messages between two or more people, with direct effects and feedback. In addition, interpersonal communication is also referred to as an exchange, which is the act of conveying and receiving messages reciprocally. Communal perceptions will be 
influenced by rhetorical models because communal perceptions about the synergy between traditional and modern ways of treating patients with mental disorders should not stop at the mental hospital environment. But it must be socialized so as to form new perceptions in the heads of each audience.

According to Aristotle, in persuasive communication, behavior change is the most important goal so that a role and awareness of the role of the audience is needed. Persuasion takes place through audiences when they are led by the speech into a certain emotional state.

But even so, this very simple model can stimulate several questions, for example: (1) what elements must be present in a speech to be persuasive to the audience? (2) Are certain forms of speech composition better than other forms ?, (3) ) Does the style of language in a speech affect the degree of persuasion? (5) Does the pre-existing speaker's reputation increase his persuasion power? The rhetorical model is compatible with the Laswell model which is commonly used in mass communication. Many sources of information are obtained from the mass media, among the many propagandas that are not necessarily high in truth.

\section{Psychological Effects on Patients}

The Stimulus-Response (S-R) model is the most basic psychological theory for explaining patient / client perceptions. This model is influenced by the discipline of psychology, especially behavioristic ones. Obviously, the model describes a StimulusResponse relationship. In a concept that focuses on the environment, basically there is always a stimulus and response in every event experienced by an individual. The events that exist require individuals to translate into someone's thought process in the form of a learning process using intrapersonal communication, because in the human psyche it consists of associations of various kinds of incoming responses that are formed due to stimuli and responses.

The Stimulus-Response Model that involves stressors and strains coupled with an important form of relationship, namely the relationship between a person and their environment that encourages a person to react and act to meet the demands that must be met. This process involves continuous interactions and adjustments called transactions, between a person and their environment where both of them influence each other. For example, simply someone who is stuck in a traffic jam and is late for an appointment keeps looking at his clock, keeps honking his car horn, and gets more and more angry every minute.

In its development, it turns out that the source of information is not only transmitted to the target, but also requires similarity in the field of experience (Field of Experience). So that and this simple model is developed again into the second model by adding elements of the field of experience (Field of Experience). So that a message can be received by the recipient of the message properly, the message that has been sent to the recipient of the message is in accordance with what was conveyed. The wider the field of experience (Field of Experience), the more effective the results obtained in the communication process.

At first glance, this does not seem like a problem, however the patient's level of understanding becomes a reference when health workers communicate with the general public or patients. This is because the field of experience of health workers is certainly not the same as the field of experience of ordinary people or patients. It is these differences that must be considered by health workers.

There is also a Newcomb model which looks at communication from a socialpsychology perspective. In view of this model, the message conveyed will be responded to both good and bad depending on how the message is perceived and the recipient is. This model is reminiscent of the group network diagram created by social psychologists and is an early formulation of cognitive consistency. In this communication model, which is often called the ABX model or the Symmetry Model, Newcomb describes 
that someone named A conveys information to another person named B about something, namely $\mathrm{X}$. The model assumes that A's orientation (attitude) towards B and towards $\mathrm{X}$ is interdependent, and all three are a system consisting of four orientations. Everything is described as (a) A's orientation towards X, which includes attitudes towards $\mathrm{X}$ as an object to be approached or avoided and cognitive attributes (belief and cognitive order), (b) A's orientation towards $\mathrm{B}$, in the same sense, (c) Orientation B to $X$, and (d) Orientation of B to A.

There are so many things that can be changed and some that cannot be changed in dealing with mental disorders. Especially when a combination of medical and conventional methods is applied. In view of optimism, it is stated that there is nothing that cannot be changed, it's just that sometimes it cannot be changed at this time. However, by knowing what things can be changed and doing activities to change them, that is a proactive attitude. The environment should not drive individually, because everyone is capable of driving the environment. In the nursing world, sectoral egoism should be reduced or even eliminated altogether.

\section{Impact of Family Power}

The effect of family power has actually been influenced by other powers that have shackled the development of human thought. The family is a sub-society that inevitably has to be carried away by this flow. The minds of people in the family are filled with the desire to achieve the truth in all of this. Truth itself is centered on the form of scientific discourse and the institutions that produce it (Shmogaki, 2011: 40).

Perception formation as experienced by the patient's family 026808 involves intrapersonal communication which, according to West and Turner (2007: 34), is communication that is carried out on oneself which consists of sensations, perceptions, memories, and thoughts. Intrapersonal communication or intrapersonal communication is the use of language or thoughts that occur within the communicator himself.

Daily activities and intra-personal communication carried out by individuals in an effort to understand themselves include praying, gratitude, self-introspection by reviewing the actions that have been done and the reactions of one's own conscience, making use of free will, and imagining creatively. This personal self-understanding develops in line with the changes that occur in a person's life. Humans are born with an understanding of who they are, but their behavior has played an important role in how they develop this personal selfunderstanding.

\section{Impact of Community Culture}

Humans are social creatures as well as individual beings. In both aspects, humans also become cultural beings who are constantly learning in their environment. As social beings, humans have a motive for making relationships and living with other people in order to fulfill basic needs which are called social drives. Humans as individual beings have a motive for making a relationship with themselves in order to evaluate themselves. The human individual needs a relationship not only with other individuals, but also with the environment in which he is located.

There are clients, family of clients, doctors, laboratory workers, and other health workers. In this shared life, there is a relationship between the nurse - client, nurse - nurse, nurse - doctor, nurse-client's family, other health care workers, and the nurseenvironment. This relationship is manifested and carried out in order to achieve the goal of nursing services, namely excellent nursing service to accelerate the healing of clients, while to achieve this need to be realized in the form of action through reciprocal relationships. This reciprocal relationship is needed in an effort to cooperate in the implementation of nursing services.

This creates an impression on the nurse who then determines what action to take. Social interaction is a form of 
relationship between individuals and their environment, especially their psychological environment. The relationship between individuals and the environment is generally carried out in order to adapt, either autoplastically or alloplastically. The continuation of individual relations with one another is to mutually adjust the deen.

In achieving this trusting relationship, it also needs to be emphasized that in the process of interaction, each other must maintain privacy so that what is discussed is open and does not cover each other. One of the main causes of deadlock in social interactions is the absence of openness to one another so that sometimes what is said is not the same as what actually happened and was wanted. In the mental nursing process at RSJ Bali Province, a trusting relationship is the key to success in the implementation of nursing services. This trusting relationship is the opening key in the implementation of the nursing process.

The hope is that there is the best possible nursing service and nurses who get accurate data and clients should provide excellent service to clients, because this is a consequence and nurses provide services. Thus, a trusting relationship is followed up with a reciprocal relationship that is mutually beneficial and must be carried out with consequences that carry risks with a human caring atmosphere. Trust is the feeling and attitude of relying on the behavior of others to achieve the desired goals, whose achievement is uncertain and in situations of risk.

There is also a form of stalemate, which is accommodation in which conflicting parties have a balanced power that stops at a certain point in their conflict. This form of accommodation minimizes horizontal disputes, because it is easy to trigger conflicts, both momentary and prolonged conflicts. Usually one party and another claim to be the truest and strongest. This power struggle has an impact on the gross road level, resulting in contention because this periphery level audience is easily ignited and easy to move.

\section{CONCLUSION}

Based on the analyst's description of the previous chapter, the following conclusions can be formulated:

(1) The factors that cause the Balinese to integrate traditional and conventional medicine are influenced by two factors, namely internal and external. Internal factors that cause Balinese to integrate traditional and conventional medicine are belief factors, the need for holistic nursing care, social factors, and cultural factors. Meanwhile, external factors that influence the Balinese integrate traditional and conventional medicine, namely the legitimacy of state regulations on traditional medicine and the weaknesses of western biomedicine which are considered not completely capable of treating patients with psychiatric disorders which of course are caused by various conditions and possibilities.

(2) The form of a combination of traditional and conventional medicine for mental disorders rehabilitation patients at RSJ Bali Province consists of various treatment systems. Traditionally what is done first is the process of listening or diagnosis, treatment of bhuta yadnya or mantras, speech, spiritual shower, prayer and handling of mental disorders contained in the text (manuscript). Conventional handling is in the form of psychoanalytic cognitive behavior approach, humanistic approach and other types of therapy. Forms of combining traditional medical techniques with modern or conventional include: diagnosis, improvement of mental development, treatment with the use of drugs and treatment in a spiritual way.

(3) The impact of integrating traditional and conventional medicine on mental patients at RSJ Bali Province consists of five main impacts, namely 1) the impact on the individual, 2) the social impact, 3) the psychological impact on the patient, 
4) the impact of family power, and 5) the impact community culture. Individually, of course, you will experience two forms of treatment techniques at once in one disease complaint, this will certainly provide a new experience for the patient. Both of these treatment techniques certainly have the same opportunity to support the patient's recovery. So that the process of healing complaints of psychiatric disorders that are felt will be resolved more quickly. In this case, of course, there will be positive and negative perceptions in the integration of traditional and conventional medical systems. This is due of course to the varied perceptions of society. This kind of situation occurs because everyone's experience in dealing with a problem, of course, has different ways of solving it. However, in accordance with the typology of Balinese society which is religiously mystical, the integration of traditional and conventional medical techniques is also considered legitimate.

\section{Suggestions}

In the research of Patients with Mental Disorders (Adiatmika Dhuka) at RSJ Bali Province Traditional Health Perspectives, the following suggestions can be made:

(1) To Hindu-based institutions so that they can further explore studies related to traditional health sciences.

(2) To the government to pay more attention to the traditional treasures which are the local geniuses of the Balinese people

(3) Researchers to be more active in conducting research on the treasures of traditional culture which are the ancestral heritage of Balinese people.

(4) For the community to always maintain traditional cultural heritage as a form of legacy of Balinese local genius.

\section{REFERENCES}

Andara, Sunarto. 2017. Persepsi Sosial. Jogjakarta: PT Pustaka Suar Abadi.

Bagus, Lorens. 2005. Kamus Filsafat. Jakarta: Gramedia
Basrowi dan Suwandi. 2008. Memahami Penelitian Kualitatif. Jakarta: Rineka Cipta.

Borysendko, Joan, 2002. The Power of The Mind to Heal, Jakarta: Gramedia Pustaka Utama.

Budiono, M.A. 2005. Kamus Lengkap Bahasa Indonesia. Surabaya: Karya Agung.

Dally, Martha. 1999. Manusia dan Psikologis. Jogjakarta: PT Angkasa Publisher

Denzin, Norman K dan Yvonnas S. Loncoln. 2009. Hanbook Of Qualitative

Drajat, Zakiah, 1980. Peranan Agama dalam Kesehatan Mental, Jakarta: Gunung Agung.

Ennis, Maeve, Parker, Jennifer. 2005.Memahami Arti Mimpi.Jakarta:PT Gelora Aksara Pratama

Foster and Anderson. 2009. Teori Kebudayaan. Bandung: Renikacipta.

Gautama, Wayan Buddha. 2004. Penuntun Pelajaran Gending Bali. Denpasar: Kayu Mas Agung.

Goldberg, Bruce. 2006.Self Hypnosis. Yogyakarta:PT Bentang Pustaka

Griya, I Wayan, 2002. Transformasi Kebudayaan Bali Memasuki Abad XXI, Denpasar: Dinas Kebudayaan Propinsi Bali.

Gunarsa, Singgih D.2007.Konseling dan Psikoterapi.Jakarta: Gunung Mulia

Guze, Barry, dkk. 1997.Buku Saku Psikiatri.Jakarta: IKAPI

Hanafiah, Jusuf. 2007.Etika Kedokteran \& Hukum Kesehatan.Jakarta: IKAPI

Hartini, Nurul, Ariana, Atika Dian. 2016.Psikologi Konseling.Surabaya: Airlangga University Press

Hasan, Iqbal. 2002. Metode Penelitian dan Aplikasinya. Jakarta: Ghalia Indonesia.

Jena, Yeremias. 2019. Wacana Tubuh dan Kedokteran: Sebuah Refleksi Filosofis.Jakarta: Penerbit UKI Atma Jaya

Koentjaraningrat, 2000. Pengantar Ilmu Antropologi. Jakarta: Rineka Cipta. 
Manuntung, Alfeus. 2018.Terapi Perilaku Kognitif Pada Pasien Hipertensi.Jakarta: Wineka Media

Masduki, Yusron, Warsah, Idi. 2020.Psikologi Agama.Palembang: IKAPI Sumsel

Moleong, Lexy J. 2010. Metodologi Penelitian Kualitatif (EdisiRevisi). Cetakan Kedua Puluh Delapan. Bandung: Rosdakarya.

Mulawarman, dkk. 2019.Psikologi Konseling.Jakarta: Kencana

Mulyana, Dedi. 2000. Metode Penelitian Kualitatif, Paradigma Baru Ilmu Komunikasi dan Ilmu Sosial Lainya. Bandung: Remaja Rosdakarya.

Murjana. 2015. Resistensi Keluarga dalam Pemulangan Klien Gangguan Kejiwaan di RSJ Bangli. Denpasar: IHDN Denpasar.

Nandor, Fodor, Gaynor, Frank. 2018.Kamus Praktis Psikoanalisis. Jogjakarta: IRCiSoD

Nawawi, H. Hadari. 2005. Metode Penelitian Sosial. Yogyakarta: Gadjah Mada Universitas Press.

Nugraheni, Hermien, dkk. 2018.Kesehatan Masyarakat Dalam Determinan Sosial Budaya.Yogyakarta: Deepblish

Prabhupada, Acarya Bhakti Vedanta Swami. 2017. Bhagavadgita Menurut Aslinya". Jakarta: Hanuman Sakti.

Putri, Dewi Murdianti Prihatin. 2018. Antropologi Kesehatan Konsep dan Aplikasi Antropologi dalam Kesehatan. Yogyakarta: Pustaka Baru Pers

Putri, Dewi Murdianti Prihatin. 2018. Keperawatan Transkultural Pengetahuan dan Praktik Berdasarkan Budaya. Yogyakarta: Pustaka Baru Pers.

Putri, Dewi Murdiyanti Prihatin. 2008. Keperawatan

Transkultural.Yogyakarta: Pustaka Baru Press

Rachmawati. 2008. Memahami Medis Personalis. Jakarta: Ungu Publisher
Ratna, Nyoman kutha. 2010. Teori, Metode, dan Tekhnik Penelitian Sastra. Yogyakarta: Pustaka Pelajar.

Reksodirardjo, Soegeng, dkk. 1991.Pengobatan Tradisional Pada Masyarakat Pedesaan Daerah Jawa Tengah.Jakarta: Departemen Pendidikan dan Kebudayaan

Research. Penerjemah Daryatno, dkk. Yogyakarta: Pustaka Pelajar

Saputa, Henri. 2018.The Counseling Way.Jakarta: Deepublish

Semi, Atar. 2012. Metode Penelitian Sastra. EdisiRevisi. Bandung: Angkasa.

Setiadai. 2008. Psikologi Sosial. Bandung: Angkasa Pura.

Simanjuntak, Julianto. 2008.Konseling Gangguan Jiwa\&Okultisme.Jakarta:PT Gramedia Pustaka Utama

Sudarma, Momon. 2008.Sosiologi Untuk Kesehatan.Jakarta: Salemba Medika

Sudarta, I Made. 1994. Upacara Melukat dalam Upacara Penyembuhan Gangguan Jiwa. Denpasar: IHDN Denpasar.

Sugiyono. 2012. Metode Penelitian Kombinasi (Mixed Methods). Cetakan Kedua. Bandung: Alfabeta.

Sugono, Dendy. 2008. Kamus Besar Bahasa Indonesia Pusat Bahasa. Jakarta: Gramedia Pustaka Utama.

Sukrawati, Wandri, Wayan. 2010.Kaedah Beryajna.Surabaya: Paramita

Sumantra, I Nengah. 2005. Pembinaan Mental Spiritual dalam Upaya Pengobatan Gangguan Jiwa di RSJ Bangli. Dempasar: IHDN Denpasar.

Sunaryo, dkk. 2015. Asuhan Keperawatan Gerontik. Yogyakarta: Andi Offset

Sundah, Ariantje J.A.2016.Konseling Analisis Transaksional. Jakarta: Makaria Jaya

Sunetra, I Made. 2002. Tehnik Pengobatan Dengan Sistem Getaran. Denpasar: PB

Supratiknya. 2006. Memahami Manusia secara Luar dan Dalam. Jakarta: Sinar Pelajar.

Suruni. 2004. Cara Kerja Otak. Jakarta: Gramedia Pustaka Utama. 
Suryani, Luh Ketut. 1988. Pisikosis Akut (Gangguan Jiwa) pada Orang Bali Beragama Hindu Suatu Studi Pendekatan Klinis Sosiocultural (memory trans atau kerauhan).

Sutejo. 2018. Keperawatan Kesehatan Jiwa Prinsip dan Praktik Asuhan Keperawatan Jiwa. Yogyakarta: Pustaka Baru Pers.

Wendra, I Wayan. 2009. Buku Ajar Penulisan Karya Ilmiah. Undiksa: Singaraja.

West, Richard, Turner, Lynn H.2007.Pengantar Teori Komunikasi.Jakarta: Salemba Humanika Wijaya, AA Prima Surya. 2010.Memahami Catur Marga. Surabaya: Paramita

Wiramiharja. 2004. Memahami Mantal Manusia. Surabaya: Yayasan Senanghati.

Wirawan, I Gusti Bagus. 2007. Sekilas Tentang Metode Dharma Wacana. Surabaya: Paramita

Yosep. 2007. Psikologi Pendidikan. Jakarta: Gramedia Pustaka Utama. 